Jurnal Informatika dan Rekayasa Perangkat Lunak (JATIKA)
Vol. 2, No. 3, September 2021, page-page. 285 303
ISSN 2723-3367
E-ISSN 2797-3492
available online at:http://jim.teknokrat.ac.id/index.php/informatika

\title{
E-COMMERCE TOKO FISAGO.CO BERBASIS ANDROID
}

\author{
Wayan Windane ${ }^{1}$, Lathifah ${ }^{2}$ \\ S1 Informatika, Universitas Teknokrat Indonesia ${ }^{1,2}$ \\ wayanwindane5@gmail.com¹, lathifah@teknokrat.ac.id²
}

Published: 30 September 2021

\begin{abstract}
The rapid development of the internet in the past decade has significantly changed entrepreneurs in marketing their goods and services, with information technology that can make it easier for producers to market and offer their products. E-commerce (Electronic Commerce) is an online channel that can be reached by someone through a computer, which is used by business people in carrying out their business activities and used by consumers to obtain information using computer assistance which in the process begins with providing information to consumers in making choices. problems with the system that is running at the Fisago.co store when the customer places an order for goods the customer must ask if the stock is available or later when confirming that he has paid for the goods for other customers who will purchase goods. With this service, it causes delays in a customer transaction. By making an android application system using the help of android studio software, it can overcome the problems that exist in the fisago.co store, of course in sales. Based on the tests that have been carried out both alpha and beta testing using the ISO 25010 testing aspect, testing the Fisago.co E-Commerce application on function suitability got a score of $94 \%$ and for usability testing it got $68 \%$ from the user side with the criteria "Good" then from the admin gets a score of $92 \%$ with the "Very Good" Criteria. In testing the portability aspect with different smartphone specifications it can be installed and can run well.
\end{abstract}

Keywords: Android Studio, E-commerce, Android App, ISO 25010, xp programming

\begin{abstract}
Abstrak
Perkembangan internet yang semakin pesat dalam satu dekade belakangan ini ternyata secara signifikan mengubah perilaku pengusaha dalam memasarkan produk barang dan layanannya, dengan adanya teknologi informai yang dapat memudahkan produsen dalam memasarkan dan menawarkan produk mereka. E-commerce (Perdagangan Elektronik) merupakan saluran online yang dapat dijangkau seseorang melalui komputer, yang digunakan oleh pebisnis dalam melakukan aktifitas bisnisnya dan digunakan konsumen untuk mendapatkan informasi dengan menggunakan bantuan komputer yang dalam prosesnya diawali dengan memberi jasa informasi pada konsumen dalam penentuan pilihan. Adapun kendala dengan sistem yang sedang berjalan pada toko Fisago.co pada saat pelanggan melakukan pemesaan barang pelanggan harus menanyakan apakah stok barang tersedia atau tidak kemudian ketika pelanggan mengkonfirmasi sudah melakukan pembayaran barang terkadang tertimpa dengan pelanggan lainnya yang akan melalukan pembelian barang. Dengan pelayanan semacam ini menyebabkan terhambatnya suatu transaksi kepada pelanggan. Dengan dibuatkannya sebuah sistem aplikasi android menggunakan bantuan software android studio dapat mengatasi permasalahan yang ada pada toko fisago.co tentunya dalam penjualan. Berdasarkan pengujian yang telah dilakukan baik pengujian alpa dan beta menggunakan aspek pengujian ISO 25010, pengujian aplikasi E-Commerce Fisago.co pada functionlity suitability mendapatkan skor $94 \%$ dan untuk pengujian usability mendapatkan $68 \%$ dari sisi pengguna dengan kriteria "Baik" kemudian dari sisi admin mendapatkan skor 92\% dengan kriteria "Sangat Baik". Pada Pengujian aspek portability dengan spesifikasi smartphone yang berbeda dapat terinstal dan dapat berjalan dengan baik.
\end{abstract}

Kata Kunci: Android Studio, perdagangan elektronik, aplikasi Android, ISO 25010, xp programming

To cite this article:

Wayan Windane, Lathifah. (2021). E-COMMERCE TOKO FISAGO.CO BERBASIS ANDROID. Jurnal Informatika dan Rekayasa Perangkat Lunak, Vol(2) No(3), 285-303. 


\section{PENDAHULUAN}

Perkembangan teknologi pada saat ini sangat menjadi prioritas di dunia (Lathifah 2020). Semakin majunya perkembangan teknologi informasi dan komputer, maka kebutuhan manusia akan informasi pun semakin meluas. Salah satu cara untuk mendapatkan informasi adalah dengan memanfaatkan fasilitas internet. Dengan internet kita dapat menghemat ruang dan waktu. Sehingga informasi yang diinginkan dapat ditemukan tanpa harus meninggalkan tempat dan aktivitas rutin kita. Meningkatnya penggunaan internet oleh masyarakat yang ditandai dengan melonjaknya costumer maupun pebisnis, mendorong munculnya suatu tuntutan pelayanan internet melebihi dari apa yang bias diperoleh didunia nyata. Ini meliputi kesempatan untuk menjual barang-barang ataupun produk-produk secara online. Salah satu hal terpenting dalam bisnis melalui internet adalah bagaimana keuntungan dapat diperoleh secara aman dan mudah. Mukaromah \& Rosadi (2015). Perkembangan internet yang semakin pesat dalam satu dekade belakangan ini ternyata secara signifikan mengubah perilaku pengusaha dalam memasarkan produk barang dan layanannya, dengan adanya teknologi informai yang dapat memudahkan produsen dalam memasarkan dan menawarkan produk mereka. Teknologi pada suatu organisasi, perusahaan, dan pemerintahan era sekarang sangat memiliki peran yang begitu besar (Lathifah et al. 2021).

Teknologi informasi merupakan sarana dan prasarana (hardware, software, useware) sistem dan metode untuk memperoleh, mengirimkan, mengolah, menafsirkan, menyimpan, mengorganisasikan, dan menggunakan data secara bermakna. Bambang Warsita (2008:135). Dengan memanfaatkan teknologi tersebut dapat juga meningkatkan omset atau penghasilan dari produk yang dijual. Teknologi yang dimaksudkan adalah E-Commerce (Perdagangan Elektronik) atau kita sering sebut juga jual beli online. E-commerce merupakan saluran online yang dapat dijangkau seseorang melalui komputer, yang digunakan oleh pebisnis dalam melakukan aktifitas bisnisnya dan digunakan konsumen untuk mendapatkan informasi dengan menggunakan bantuan komputer yang dalam prosesnya diawali dengan memberi jasa informasi pada konsumen dalam penentuan pilihan. Kotler \& Amstrong (2012). Dengan memanfaatkan teknologi informasi dan e-commerce pada penelitian ini akan dibuatkan sebuah sistem berbasis android, Android merupakan sebuah kumpulan perangkat lunak untuk perangkat mobile yang mencakup sistem operasi middleware dan aplikasi utama mobile. (Safaat,2012). Perangkat android yang dapat menggunakan aplikasi ini misalnya, OPPO, REALMI, dan sebagainya.

Toko Fisago.co didirikan oleh renji pada tahun 2017 dengan alamat Jalan Nusantara Mulyosari Kota Metro Lampung. Toko Fisago.co bergerak di bidang penjualan produk khususnya pakaian polos produk yang dihasilkan antara lain kaos polos, baju berkerah polos, dan hudi polos. Saat ini toko Fisago.co memiliki aktifitas yaitu memproduksi pakaian polos kemudian memasarkan produksi, Sistem yang sedang berjalan pada toko Fisago.co memasarkan produksi yang dihasilkan hanya memanfaatkan media sosial berupa Instagram. Adapun kendala dengan sistem yang sedang berjalan pada toko Fisago.co pada saat pelanggan melakukan pemesaan barang pelanggan harus menanyakan apakah stok barang tersedia atau tidak kemudian ketika pelanggan mengkonfirmasi sudah melakukan pembayaran barang terkadang tertimpa dengan pelanggan lainnya yang akan melalukan pembelian barang. Dengan pelayanan semacam ini menyebabkan terhambatnya suatu transaksi kepada pelanggan.

Kondisi serta kebutuhan pada toko fisago.co, penelitian membangun sebuah aplikasi E-Commerce untuk meningkatkan pelayanan penjualan berbasis android yang berjudul " Rancang Bangun Aplikasi E-Commerce Toko Fisago.co Berbasis Android". Harapannya agar dapat membantu dalam penjualan produknya, dapat meningkatkan penjualan memalui aplikasi berbasis android yang akan dibuat.

\section{TELAAH PUSTAKA \\ Rancang Bangun}

Rancang Bangun merupakan tahap dari setelah analisis dari siklus pengembangan sistem yang merupakan pendefinisian dari kebutuhan-kebutuhan fungsional, serta menggambarkan bagaimana suatu sistem dibentuk yang dapat berupa penggambaran, perencanaan, dan pembuatan sketsa atau pengaturan dari beberapa elemen yang terpisah ke dalam satu kesatuan yang utuh dan berfungsi, termasuk menyangkut mengkonfigurasikan dari komponen-komponen perangkat keras dan perangkat lunak dari suatu sistem. (Jogiyanto, 2005:197).

\section{Aplikasi}

Aplikasi merupakan penerapan pengimplementasian suatu hal, data, permasalahan, pekerjaan kedalam suatu sarana atau media yang dapat digunakan untuk menerapkan atau mengimplementasikan hal atau permasalahan tersebut sehingga berubah menjadi suatu bentuk yang baru, tanpa menghilangkan nilai-nilai dasar dari hal, data, permasalahan atau pekerjaan. (Setiawati, 2009:9). 


\section{E-Commerce}

Internet Commerce atau Ecom atau ECommerce atau Immerce yang pada dasarnya semua sebutan diatas mempunyai makna yang sama. Istilah-istilah tersebut berati membeli atau menjual secara elektronik dan kegiatan ini dilakukan pada jaringan internet. E-commerce atau dapat disebut perdagangan elektronik adalah penyebaran, pembelian, penjualan, pemasaran barang dan jasa melalui sistem elektronik seperti internet atau televisi, radio dan jaringan komputer lainnya (Jony, 2010:33).

\section{Android}

Android merupakan sistem operasi berbasis linux yang digunakan untuk perangkat mobile atau perangkat tablet (PDA). Android menyediakan platform terbuka bagi para pengembang untuk mengembangkan aplikasi buatan sendiri yang membuat android menjadi sistem operasi mobile yang populer hingga saat ini. Android didirikan pada tahun 2003 oleh Andy Rubin, Nick Sears, Rich Miner dan Chris White yang kemudian dibeli oleh Google pada bulan Juli 2005.

\section{Metode Extreme Programming (XP)}

Extreme Programming adalah metodologi pengembangan perangkat lunak yang ditujukan untuk meningkatkan kualitas perangkat lunak dan tanggap terhadap perubahan kebutuhan pelanggan. Jenis pengembangan perangkat lunak semacam ini dimaksudkan untuk meningkatkan produktivitas dan memperkenalkan pro pemeriksaan dimana persyaratan pelanggan baru dapat diadopsi (Pressman, 2009).

\section{METODE PENELITIAN}

\section{Tahapan Penelitian}

Tahapan penelitian adalah sebuah langkah untuk melakukan sebuah penelitian yang dilakukan penulis.

Dibawah ini merupakan sebuah tahapan-tahapan penelitian yang dilakukan oleh penulis.

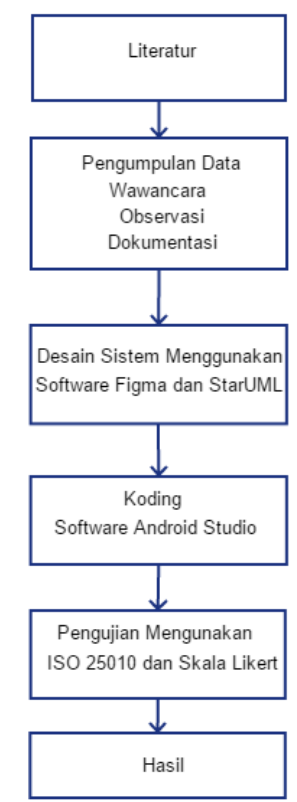

Gambar 1 Tahap Penelitian

Penjelasan pada tahap penelitian pada gambar 1 sebagai berilkut.

a. Literatur 
Dilakukan dengan cara membaca, mengutip dan membuat catatan yang bersumber pada bahan-bahan pustaka yang berkaitan dalam pembuatan aplikasi $e$-commerce berbasis android. Selanjutnya mempelajari jurnal dan buku sebagai referensi yang berhubungan dengan masalah yang akan dibahas.

b. Metode Pengumpulan Data

1. Wawancara : melakukan wawancara langsung dengan pemilik Toko Fisago.co untuk mendaptkan informasi yang dibutuhkan sebagai bahan penulis laporan.

2. Observasi : mendapatkan informasi dan fakta langsung dari pengamatan di lokasi penelitian pada Toko Fisago.co.

3. Dokumentasi : dilakukan dengan mengambil foto yang diperlukan untuk dokumentasi bahan lampiran laporan untuk memperkuat peneliti bahwa sesuai dengan keadaan yang ada.

c. Desain Sistem

Pada desain sistem ini penulis menggunakan software starUML untuk pembuatan diagram UML dan untuk pembuatan rancangan interface penulis menggunakan software figma.

d. Koding

Setelah tahapan desain sistem selesai dibuat penulis melakukan pengumpulan asset yang diperlukan kemudian membuat aplikasi menggunakan software Android Studio.

e. Pengujian

Pengujian aplikasi dilakukan untuk mengetahui kekurangan pada aplikasi yang telah dibuat penulis menggunakan aspek pengujian Functionality Suitability dan pengujian beta menggunakan aspek Usability dan Portability Dengan menggunakan pengujian ISO 25010.

\section{HASIL DAN PEMBAHASAN}

Hasil perancangan merupakan hasil dari pembuatan desain yang telah dirancang sebelumnya kemudian diimplementasikan ke dalam kode program menggunakan software Android Studio dan Mysql sebagai Database. Penulis melakukan dua implementasi Admin dan pelanggan.

\section{Admin}

Implementasi dari Admin yang nantinya untuk melakukan penambahan barang, edit barang, hapus barang dan konfirmasi pembayaran dari pelanggan.

\section{Menu Menampilkan Barang}

Pada activity ini semua barang yang di upload oleh admin akan ditampilkan pada aktivity ini.

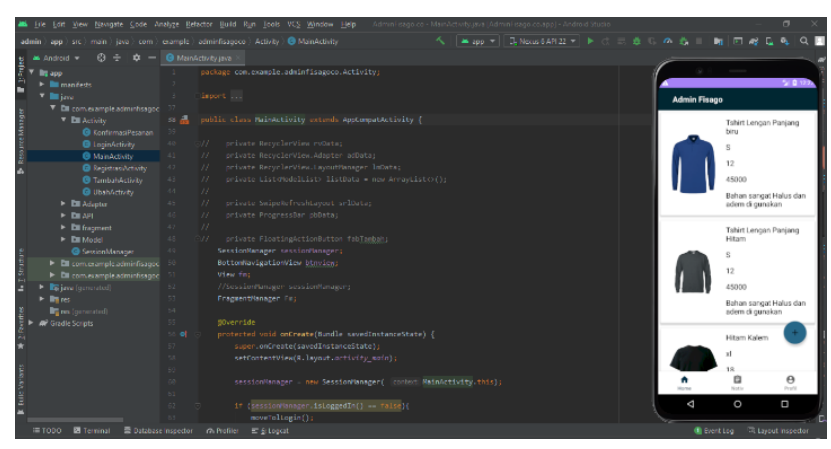


Gambar 2. Menu Menampilkan Barang

\section{Menu Tambah Barang}

Pada activity ini admin dapat melalukan upload data barang dan akan langsung tersimpan kedatabase.

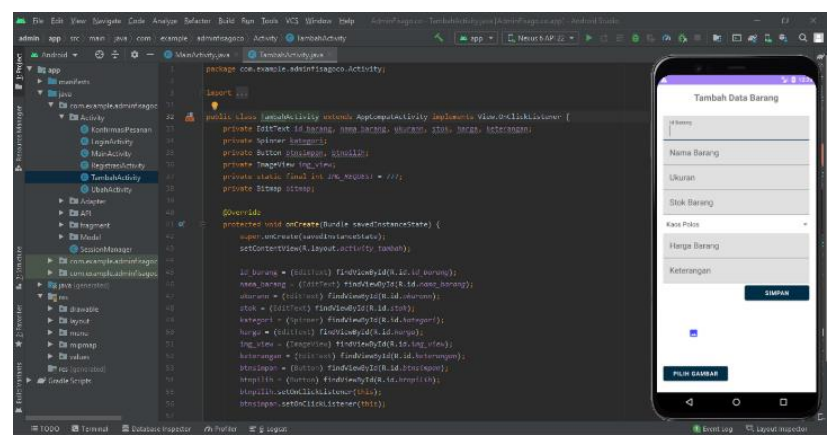

Gambar 3. Menu Tambah Barang

\section{Menu Informasi Stok}

Pada menu informasi stok barang ketika pelanggan akan melaukan pembelian barang maka stok barang otomatis berkurang.

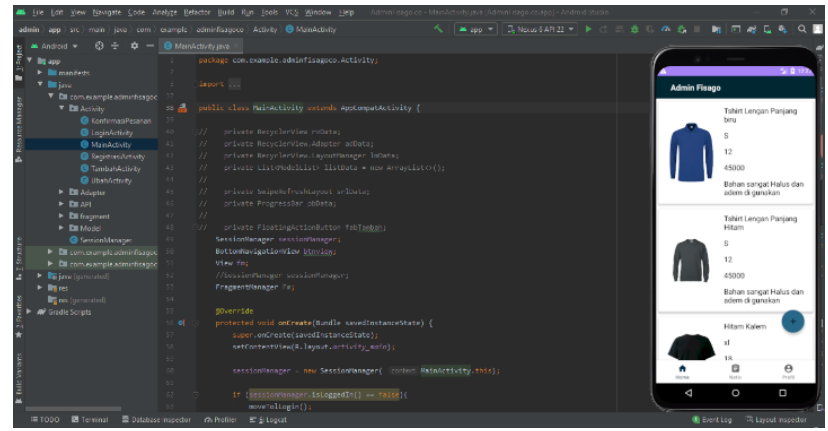

Gambar 4. Menu Informasi Stok

\section{Pelanggan}

Implementasi pada sistem Pelanggan yaitu melakukan pemesanan barang, melihat ketersedian stok barang dan konfirmasi pembayaran.

\section{Menu Home}

Pada menu ini semua barang ditampilkan dan pelanggan dapat melihat informasi barang seperti nama, harga dan stok. 


\section{Menu Detail Barang}

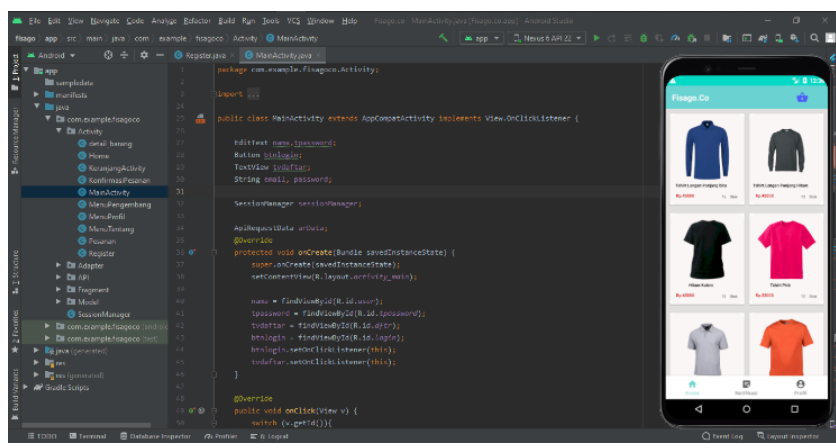

Gambar 5. Menu Home

Pada menu ini menampilkan sebuah detail informasi barang kemudian pelanggan bisa melakukan pemesanan barang dan dapat memasukan jumlah barang yang ingin dipesan.

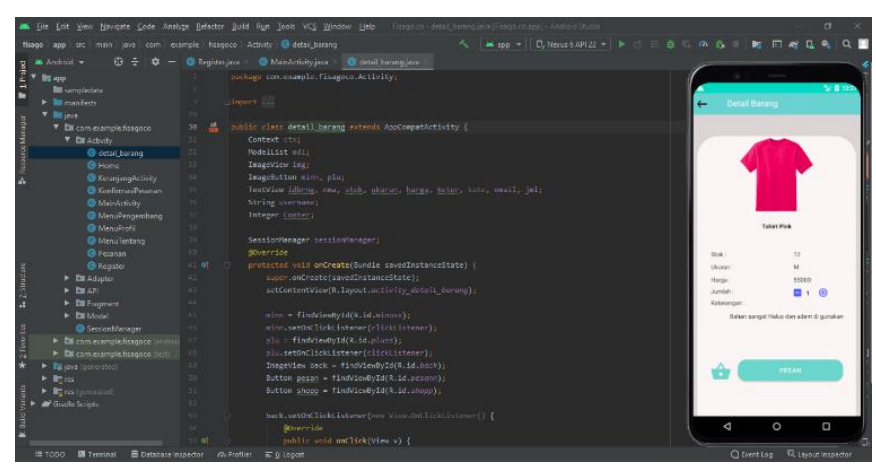

Gambar 6. Menu Detail Barang

\section{Menu Detail Pemesanan}

Pada menu ini menampilkan barang yang ingin dipesan kemudian menampilkan sebuah informasi dari pemesan yaitu alamat, nomor telepon dan total harga yang akan dibayar, dan juga terdapat informasi nomor rekening untuk melakukan pembayaran dengan cara via transfer.

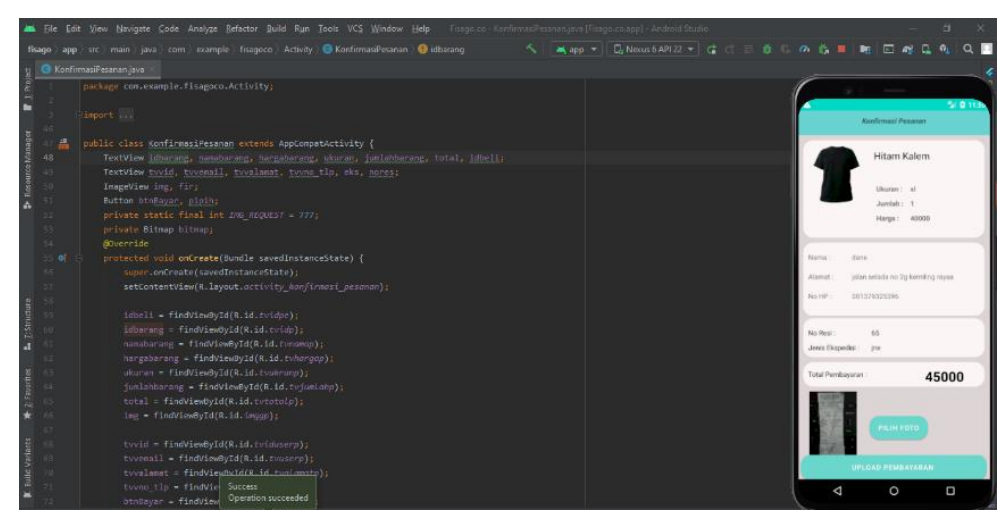

Gambar 7. Menu Detail Pemesanan

\section{Menu Informasi Jasa Pengiriman}

Menu informasi jasa pengiriman menampilkan informasi nomor resi dan nama ekspedisi agar pelanggan dapat tracking posisi barang. 


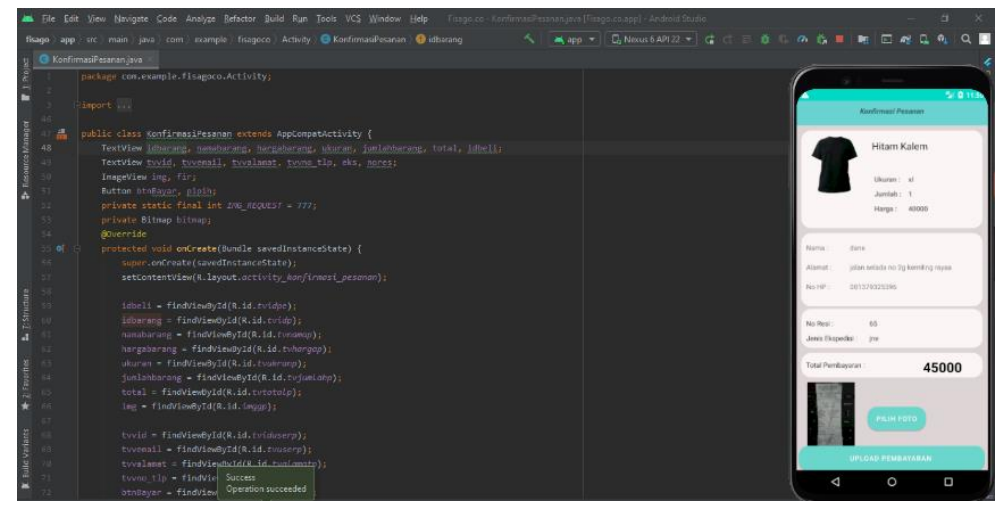

Gambar 8. Menu Informasi Jasa Pengirimana

\section{Pengujian Aplikasi}

\section{Pengujian Aspek Functionality}

Pada pengujian ini melaukan pengujian pada fungsi-fungsi yang terdapat pada aplikasi yang telah dibuat. Pengujian dilakukan oleh ahli dibidang software engineering yaitu sebanyak dua orang.

Tabel 1. Bobot Jawaban Functionality

\begin{tabular}{|c|c|c|}
\hline Jawaban & Ya & Tidak \\
\hline Bobot & 1 & 0 \\
\hline \multicolumn{2}{|c|}{ Sumber: (Sugiyono, 2018) } \\
\multicolumn{2}{|c|}{}
\end{tabular}

Dibawah ini merupakan kriteria penilaian klasifikasi skor :

- Klasifikasi Persentase $=\frac{\text { Bobot Jawaban }}{\text { Bobot Jawaban Maksimal }} \times 100 \%$

- Persentase nilai, Ya $=\frac{1}{1} \times 100 \%=100 \%$

- Persentase nilai, Tidak $=\frac{0}{1} \times 100 \%=0 \%$

Dengan berdasarkan penjelasan diatas, dapat digambarkan menggunakan sebuah skala yaitu untuk mengetahui yang hasil dari bagian tidak atau ya, dapat digambarkan sebagai berikut.

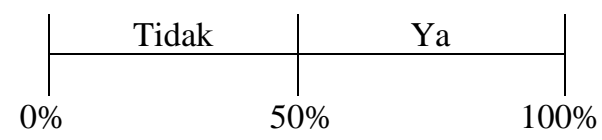

\section{Gambar 5. 1 Kualifikasi Skala Pengukuran Functionality}

Sumber: (Sugiyono, 2018)

Berikut merupakan hasil dari pengujian functional suitability yang dilakukan oleh dua responden :

Tabel 2. Hasil Pengujian functional suitability

\begin{tabular}{|c|c|c|c|}
\hline \multirow{2}{*}{ No } & Pertanyaan & \multicolumn{3}{|c|}{ Hasil } \\
\cline { 3 - 4 } & Berhasil & Gagal & Skor \\
\hline \multicolumn{2}{|c|}{ Sub Karakteristik Functional Completeness } & & \\
\hline
\end{tabular}




\begin{tabular}{|c|c|c|c|c|}
\hline 1 & Menampilkan halaman login & 2 & 0 & 2 \\
\hline 2 & $\begin{array}{l}\text { Saat form login diisi dengan benar kemudian tekan } \\
\text { tombol login akan menampilkan halaman menu utama }\end{array}$ & 2 & 0 & 2 \\
\hline 3 & $\begin{array}{l}\text { Saat tombol registrasi pada Menu Login di tekan akan } \\
\text { Menampilkan halaman Registrasi }\end{array}$ & 2 & 0 & 2 \\
\hline 4 & $\begin{array}{l}\text { Pada halaman Registrasi saat form diisi kemudian } \\
\text { tombol registrasi di tekan akan menampilkan halaman } \\
\text { login. }\end{array}$ & 2 & 0 & 2 \\
\hline 5 & $\begin{array}{l}\text { Saat tombol login pada halaman Registrasi di tekan } \\
\text { akan } \\
\text { Menampilkan halaman Registrasi }\end{array}$ & 2 & 0 & 2 \\
\hline 6 & $\begin{array}{l}\text { Pada halaman menu utama menampilkan gambar dan } \\
\text { informasi barang }\end{array}$ & 2 & 0 & 2 \\
\hline 7 & $\begin{array}{l}\text { Pada halaman menu utama di tekan salah satu } \\
\text { gambar/objek akan berpindah ke halaman detail barang }\end{array}$ & 2 & 0 & 2 \\
\hline 8 & $\begin{array}{l}\text { Pada halaman detail barang menampilkan gambar dan } \\
\text { infomasi barang }\end{array}$ & 2 & 0 & 2 \\
\hline 9 & $\begin{array}{l}\text { Pada halaman detail barang saat form jumlah diisi } \\
\text { kemudian tombol pesan di tekan akan berpindah ke } \\
\text { halaman detail pemesanan }\end{array}$ & 2 & 0 & 2 \\
\hline 10 & $\begin{array}{l}\text { Pada halaman detail pemesanan menampilkan infomasi } \\
\text { pemesanan barang }\end{array}$ & 2 & 0 & 2 \\
\hline 11 & $\begin{array}{l}\text { Pada halaman detail pemesanan kemudian tombol bayar } \\
\text { di tekan akan berpindah ke halaman metode } \\
\text { pembayaran dan muncul notifikasi pemesanan berhasil } \\
\text { disimpan }\end{array}$ & 2 & 0 & 2 \\
\hline 12 & $\begin{array}{l}\text { Pada halaman detail barang kemudian tombol tanda } \\
\text { panah di tekan akan berpindah ke halaman utama }\end{array}$ & 2 & 0 & 2 \\
\hline 13 & $\begin{array}{l}\text { Pada halaman detail barang kemudian tombol gambar } \\
\text { keranjang ditekan akan menampilkan notif barang } \\
\text { ditambah ke keranjang }\end{array}$ & 2 & 0 & 2 \\
\hline 14 & $\begin{array}{l}\text { Pada halaman menu utama kemudian gambar keranjang } \\
\text { di tekan akan menampilkan daftar barang }\end{array}$ & 2 & 0 & 2 \\
\hline 15 & $\begin{array}{l}\text { Pada halaman keranjang saat checkbox di tekan, barang } \\
\text { akan terpilih dan menampilkan total bayar }\end{array}$ & 0 & 2 & 0 \\
\hline 16 & $\begin{array}{l}\text { Pada halaman keranjang saat checkbox pilih semua di } \\
\text { tekan, checkbox barang otomatis terceklis dan } \\
\text { menampilkan total bayar }\end{array}$ & 0 & 2 & 0 \\
\hline 17 & $\begin{array}{l}\text { Pada halaman keranjang saat checkbox di tekan, barang } \\
\text { akan terpilih dan menampilkan total bayar kemudian } \\
\text { tombol pesan di tekan akan berpindah pada halaman } \\
\text { Detail pemesanan }\end{array}$ & 0 & 2 & 0 \\
\hline
\end{tabular}

Tabel 3. Hasil Pengujian functional suitability

\begin{tabular}{|c|l|c|c|c|}
\hline 18 & $\begin{array}{l}\text { Pada halaman menu utama kemudian tombol notif di } \\
\text { tekan akan menampilkan barang yang telah dipesan }\end{array}$ & 2 & 0 & 2 \\
\hline 19 & Pada halaman notifikasi jika barang di tekan akan & 2 & 0 & 2 \\
\hline
\end{tabular}




\begin{tabular}{|c|c|c|c|c|}
\hline & $\begin{array}{l}\text { berpindah ke halaman konfirmasi pemesanan dan } \\
\text { menampilkan informasi data barang }\end{array}$ & & & \\
\hline 20 & $\begin{array}{l}\text { Pada halaman konfirmasi pemesanan ketika tombol pilih } \\
\text { foto di tekan akan masuk ke galeri }\end{array}$ & 2 & 0 & 2 \\
\hline 21 & $\begin{array}{l}\text { Ketika berada di galeri kemudian memilih salah satu foto } \\
\text { maka foto akan tampil di konfirmasi pemesanan }\end{array}$ & 2 & 0 & 2 \\
\hline 22 & $\begin{array}{l}\text { Pada halaman konfirmasi pemesanan jika foto sudah } \\
\text { terpilih kemudian tombol upload pembayaran di tekan } \\
\text { akan menampilkan notif berhasil di kirim }\end{array}$ & 2 & 0 & 2 \\
\hline 23 & $\begin{array}{l}\text { Pada halaman menu utama kemudian tombol profil di } \\
\text { tekan akan menampilkan informasi pengguna }\end{array}$ & 2 & 0 & 2 \\
\hline 24 & $\begin{array}{l}\text { Pada halaman menu profil Saat gambar pensil di tekan } \\
\text { akan menampilkan halaman edit profil }\end{array}$ & 2 & 0 & 2 \\
\hline 25 & $\begin{array}{l}\text { Pada halaman edit profil kemudian form alamat diubah } \\
\text { kemudian tekan tombol simpan akan muncul notifikasi } \\
\text { berhasil disimpan }\end{array}$ & 2 & 0 & 2 \\
\hline 26 & $\begin{array}{l}\text { Pada halaman edit profil kemudian tombol keluar di } \\
\text { tekan akan berpindah ke halaman utama }\end{array}$ & 2 & 0 & 2 \\
\hline 27 & $\begin{array}{l}\text { Ketika berada di halaman login kemudian tombol kembali } \\
\text { di tekan aplikasi akan keluar }\end{array}$ & 2 & 0 & 2 \\
\hline 28 & $\begin{array}{l}\text { Saat tombol Tentang Aplikasi ditekan akan menampilkan } \\
\text { Halaman Tentang Aplikasi }\end{array}$ & 2 & 0 & 2 \\
\hline 29 & $\begin{array}{l}\text { Saat tombol Kembali pada halaman Tentang Aplikasi } \\
\text { ditekan Akan kembali ke Menu Utama }\end{array}$ & 2 & 0 & 2 \\
\hline 30 & $\begin{array}{l}\text { Saat tombol Profil Pengembang pada halaman menu } \\
\text { profil di tekan akan menampilkan halaman Profil } \\
\text { Pengembang }\end{array}$ & 2 & 0 & 2 \\
\hline 31 & $\begin{array}{l}\text { Saat tombol Kembali pada halaman Profil Pengembang } \\
\text { ditekan Akan kembali ke Menu Utama }\end{array}$ & 2 & 0 & 2 \\
\hline 32 & $\begin{array}{l}\text { Saat tombol Keluar pada menu profil ditekan akan } \\
\text { Memunculkan popup konfirmasi keluar }\end{array}$ & 2 & 0 & 2 \\
\hline 33 & $\begin{array}{l}\text { Saat tombol Ya pada popup konfrimasi keluar ditekan } \\
\text { aplikasi Akan pindah ke halaman login }\end{array}$ & 2 & 0 & 2 \\
\hline 34 & $\begin{array}{l}\text { Saat tombol Tidak pada popup konfrimasi keluar ditekan } \\
\text { akan Kembali ke Menu Profil }\end{array}$ & 2 & 0 & 2 \\
\hline \multicolumn{5}{|c|}{ Sub Karakteristik Functional Appropriatness } \\
\hline 35 & Dapat menampilkan informasi data barang & 2 & 0 & 2 \\
\hline 36 & Dapat menampilkan notifikasi jika form tidak diisi & 2 & 0 & 2 \\
\hline \multicolumn{5}{|c|}{ Sub Karakteristik Functional Correctness } \\
\hline 37 & Dapat menampilkan notifikasi jika terdapat error & 2 & 0 & 2 \\
\hline & Total & & & 68 \\
\hline
\end{tabular}

Berdasarkan dari total skor yang sudah dihitung pada tabel 5.2 diatas, kemudian dihitung dengan menggunakan skala likert, sebagai berikut :

$$
\text { Hasil }=\frac{\text { Skor diperoleh }}{\text { Skor Maksimal }} \times 100 \%
$$




$$
\begin{aligned}
\text { Hasil } & =\frac{68}{72} \times 100 \% \\
\text { Hasil } & =94 \%
\end{aligned}
$$

Berdasarkan dari perhitungan diatas, menghasilkan persentase sebesar 94\% yang dapat disimpulkan bahwa aspek Functionality Suitability yang dinilai oleh responden "Berhasil" dibuat karena memenuhi kriteria persentase hasil uji. Berikut tabel presentase

Tabel 4. Presentase Functionality Suitability

\begin{tabular}{|c|l|c|c|c|}
\hline No & \multicolumn{1}{|c|}{ Nama } & $\begin{array}{c}\text { Total } \\
\text { Responden }\end{array}$ & $\begin{array}{c}\text { Hasil } \\
\text { Perhitungan }\end{array}$ & Presentase \\
\hline 1 & Functional Completeness & 62 & 91 & $91 \%$ \\
\hline 2 & Functional Appropriatness & 4 & 100 & $100 \%$ \\
\hline 3 & Functional Correctness & 1 & 100 & $100 \%$ \\
\hline
\end{tabular}

Dari tabel diatas kemudian di presentasekan menjadi sebuah gambar sebagai berikut.

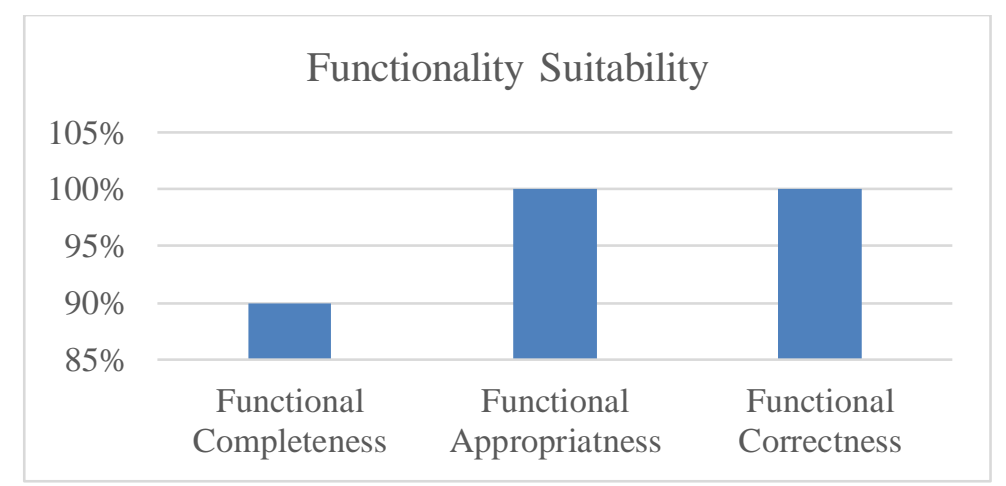

Gambar 6. Total Presentase Functionality Suitability

Berdasarkan gambar diatas menjelaskan bahwa pada funtional completeness terdapat $9 \%$ gagal dan $91 \%$ berhasil masih terdapat beberapa fungsi yang tidak jalan pada aplikasi E-Commerce fisago.co.

\section{Pengujian Aspek Usability}

Pengujian aspek usability dilakukan untuk mengukur kemampuan dan kualitas dari aplikasi yang terdiri dari kemudahan penggunaan aplikasi, kesesuain dengan materi yang akan dibahas, tampilan aplikasi, serta bagaimana aplikasi dapat berfungsi dengan baik dan benar sesuai dengan apa yang diharapkan oleh pengguna. Pada pengujian usability dibagi menjadi dua yaitu admin pengguna.

\section{Pengujian Aspek Usability Admin}

Dengan responden dua orang yang berisi sebanayak 22 pertanyaan

Tabel 5. Skor Penilaian Sklala Likert

\begin{tabular}{|c|c|c|c|c|}
\hline SS & S & KS & TS & STS \\
\hline 5 & 4 & 3 & 2 & 1 \\
\hline
\end{tabular}

Tabel 6. Hasil Pengujian Usability Admin

\begin{tabular}{|c|c|c|c|c|c|c|c|}
\hline \multirow{2}{*}{ No } & Instrumen & SS & S & KS & TS & STS & \multirow{2}{*}{ Skor } \\
& & $(5)$ & $(4)$ & $(3)$ & $(2)$ & $(1)$ & \\
\hline
\end{tabular}




\begin{tabular}{|c|c|c|c|c|c|c|c|}
\hline \multicolumn{8}{|c|}{ Appropriateness Recognizability } \\
\hline 1 & $\begin{array}{l}\text { Apakah sistem ini dapat } \\
\text { menampilkan barang? }\end{array}$ & 2 & 0 & 0 & 0 & 0 & 10 \\
\hline 2 & $\begin{array}{l}\text { Apakah sistem ini dapat upload } \\
\text { data barang? }\end{array}$ & 1 & 1 & 0 & 0 & 0 & 9 \\
\hline 3 & $\begin{array}{l}\text { Apakah sistem ini dapat } \\
\text { menampilkan data barang yang } \\
\text { telah diupload? }\end{array}$ & 1 & 1 & 0 & 0 & 0 & 9 \\
\hline 4 & $\begin{array}{l}\text { Apakah sistem ini dapat menghapus } \\
\text { data barang? }\end{array}$ & 2 & 0 & 0 & 0 & 0 & 10 \\
\hline 5 & $\begin{array}{l}\text { Apakah sistem ini dapat ubah data } \\
\text { barang? }\end{array}$ & 2 & 0 & 0 & 0 & 0 & 10 \\
\hline 6 & $\begin{array}{l}\text { Apakah sistem ini terkoneksi ke } \\
\text { database? }\end{array}$ & 1 & 1 & 0 & 0 & 0 & 9 \\
\hline 7 & $\begin{array}{l}\text { Apakah sistem ini menampilkan } \\
\text { barang yang dipesan pelanggan? }\end{array}$ & 1 & 1 & 0 & 0 & 0 & 9 \\
\hline \multicolumn{8}{|c|}{ Operability } \\
\hline 8 & $\begin{array}{l}\text { Apakah sistem ini menampilkan } \\
\text { data barang secara detail? }\end{array}$ & 1 & 1 & 0 & 0 & 0 & 9 \\
\hline 9 & Aplikasi ini mudah dipakai? & 1 & 1 & 0 & 0 & 0 & 9 \\
\hline 10 & $\begin{array}{l}\text { Aplikasi ini mudah untuk } \\
\text { dipahami? }\end{array}$ & 1 & 1 & 0 & 0 & 0 & 9 \\
\hline 11 & $\begin{array}{l}\text { Tidak terdapat kesulitan dalam } \\
\text { menggunakan aplikasi ini? }\end{array}$ & 1 & 1 & 0 & 0 & 0 & 9 \\
\hline 12 & $\begin{array}{l}\text { Apakah sistem ini menampilkan } \\
\text { data barang secara detail? }\end{array}$ & 1 & 1 & 0 & 0 & 0 & 9 \\
\hline 13 & $\begin{array}{l}\text { Apakah aplikasi ini sudah berjalan } \\
\text { sesuai dengan aturan? }\end{array}$ & 2 & & 0 & 0 & 0 & 10 \\
\hline \multicolumn{8}{|c|}{ Learnability } \\
\hline 14 & $\begin{array}{l}\text { Saya belajar menggunakan aplikasi } \\
\text { ini dengan cepat dan mudah }\end{array}$ & 1 & 1 & 0 & 0 & 0 & 9 \\
\hline 15 & $\begin{array}{l}\text { Saya mudah mengingat cara } \\
\text { menggunakan aplikasi ini }\end{array}$ & 0 & 2 & 0 & 0 & 0 & 8 \\
\hline 16 & Aplikasi ini mudah dipelajari & 1 & 1 & 0 & 0 & 0 & 9 \\
\hline \multicolumn{8}{|c|}{ User Interfaces Aesthetic } \\
\hline 17 & Saya puas dengan aplikasi ini & 1 & 1 & 0 & 0 & 0 & 9 \\
\hline 18 & $\begin{array}{l}\text { Apakah kesesuian pada tampilan } \\
\text { aplikasi ini baik? }\end{array}$ & 0 & 2 & 0 & 0 & 0 & 8 \\
\hline
\end{tabular}

Tabel 7. Hasil Pengujian aspek Usability Admin (Lanjutan)

\begin{tabular}{|c|c|c|c|c|c|c|c|}
\hline \multirow{2}{*}{ No } & Instrumen & SS & S & KS & TS & STS & \multirow{2}{*}{ Skor } \\
& User Error Protection & $(\mathbf{5})$ & $\mathbf{( 4 )}$ & $\mathbf{( 3 )}$ & $\begin{array}{c}\mathbf{( 2 )} \\
\mathbf{( 1 )}\end{array}$ & Skor \\
\hline \multicolumn{2}{|c|}{} \\
\hline
\end{tabular}




\begin{tabular}{|c|c|c|c|c|c|c|c|}
\hline 19 & $\begin{array}{l}\text { Jika ada kolom yang tidak diisi maka } \\
\text { keluar notifikasi }\end{array}$ & 1 & 1 & 0 & 0 & 0 & 9 \\
\hline \multicolumn{8}{|c|}{ Accessibility } \\
\hline 20 & $\begin{array}{l}\text { Apakah dengan dibuatkannya aplikasi } \\
\text { E-Commerce dapat mempermudah } \\
\text { admin dalam penjualan barang? }\end{array}$ & 1 & 1 & 0 & 0 & 0 & 9 \\
\hline 21 & $\begin{array}{l}\text { Apakah sistem ini dibuat sesuai } \\
\text { kebutuhan? }\end{array}$ & 1 & 1 & 0 & 0 & 0 & 9 \\
\hline 22 & $\begin{array}{l}\text { Apakah dengan dibuatkannya aplikasi } \\
\text { E-Commerce dapat mempermudah } \\
\text { admin dalam menerima pesanan? }\end{array}$ & 2 & 0 & 0 & 0 & 0 & 10 \\
\hline \multicolumn{7}{|c|}{ Total } & 201 \\
\hline
\end{tabular}

Berdasarkan hasil pengujian pada aspek usability diatas, maka diperoleh skor pengujian sebesar 201, untuk skor maksimal pada pengujian usability didapatkan jika semua responden menjawab "Sangat Setuju" kemudian dikalikan dengan jumlah pertanyaan. Jadi skor maksimal yaitu (5 x 2) x $22=220$. jika dihitung menggunakan skala Likert dan hasil kriteria bisa dilihat sebagai berikut.

Tabel 8. Kriteria Interpretasi Tanggapan Responden

\begin{tabular}{|c|c|l|}
\hline \multicolumn{1}{|l|}{ No } & Nilai & Hasil \\
\hline 1 & $80 \%-100 \%$ & Sangat Baik \\
\hline 2 & $60 \%-79 \%$ & Baik \\
\hline 3 & $40 \%-59 \%$ & Netral \\
\hline 4 & $20 \%-39 \%$ & Buruk \\
\hline 5 & $0 \%-19 \%$ & Sangat Buruk \\
\hline
\end{tabular}

Sumber: (Sugiyono, 2015)

$$
\begin{aligned}
\text { Hasil } & =\frac{\text { Skor diperoleh }}{\text { Skor Maksimal }} \times 100 \% \\
\text { Hasil } & =\frac{201}{220} \times 100 \% \\
\text { Hasil } & =91 \%
\end{aligned}
$$

Berdasarkan kriteria tanggapan responden pada tabel diatas maka hasil pengujian usability pada aplikasi Admin Fisago.co mendapatkan skor 91\% dapat disimpulkan bahwa aplikasi ini mendapatkan respon Sangat Baik dari responden admin. Kemudian usability di presentase menjadi menjadi sebuah tabel hasilnya dapat dilihat pada tabel sebagai berikut.

Tabel 9. Tabel Presentase Usability Admin

\begin{tabular}{|l|l|c|c|c|}
\hline No & Nama & $\begin{array}{c}\text { Total } \\
\text { Responden }\end{array}$ & $\begin{array}{c}\text { Hasil } \\
\text { Perhitungan }\end{array}$ & Presentase \\
\hline
\end{tabular}


Jurnal Informatika dan Rekayasa Perangkat Lunak (JATIKA), Vol: 2, No: 3, 285-303

\begin{tabular}{|c|l|c|c|c|}
\hline 1 & Appropriateness Recognizability & 66 & 94 & $94 \%$ \\
\hline 2 & Operability & 55 & 91 & $91 \%$ \\
\hline 3 & Learnability & 26 & 86 & $86 \%$ \\
\hline 4 & User Interfaces Aesthetic & 17 & 85 & $85 \%$ \\
\hline 5 & User Error Protection & 9 & 90 & $90 \%$ \\
\hline 6 & Accessibility & 28 & 93 & $93 \%$ \\
\hline
\end{tabular}

Hasil dari tabel 5.10 kemudian dipresentasekan menjadi sebuah gambar 5.3 sebagai berikut.

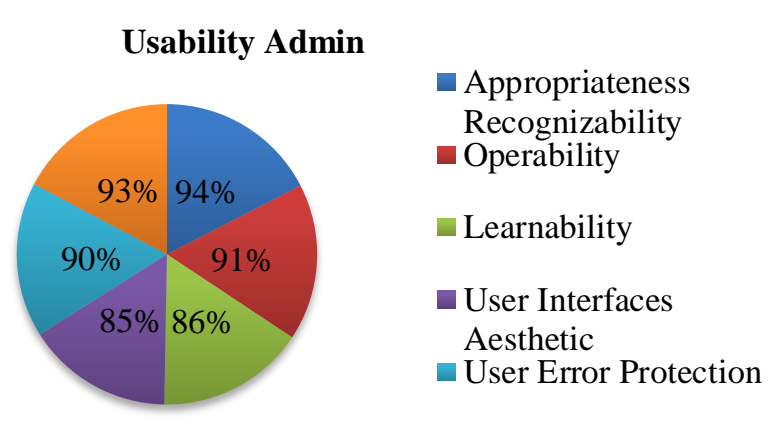

Gambar 7 Total Presentase aspek Usability Admin

Berdasarkan gambar 5.3 menjelaskan bahwa Appropriateness Recognizability mendapatkan respon yang baik dari admin.

\section{Pengujian Aspek Usability Pengguna}

Pengujian aspek usability pengguna dengan responden 8 orang yang berisi sebanyak 20 pertanyaan dengan bobot penilaian menggunakan skala likert. Tabel penilaian skala likert dapat dilihat pada tabel berikut.

\section{Tabel 10. Skor Penilaian Sklala Likert}

\begin{tabular}{|c|c|c|c|c|}
\hline SS & S & KS & TS & STS \\
\hline 5 & $\mathbf{4}$ & $\mathbf{3}$ & $\mathbf{2}$ & $\mathbf{1}$ \\
\hline
\end{tabular}

Sumber : (Sugiyono, 2012) ini.

Berikut merupakan hasil dari pengujian usability yang dilakukan oleh dua responden pada tabel berikut

Tabel 11. Hasil Pengujian aspek Usability Pengguna 


\begin{tabular}{|c|c|c|c|c|c|c|c|}
\hline No & Instrumen & $\begin{array}{l}\text { SS } \\
(5)\end{array}$ & $\begin{array}{l}\mathrm{S} \\
(4)\end{array}$ & $\begin{array}{l}\text { KS } \\
(3)\end{array}$ & $\begin{array}{l}\text { TS } \\
(2)\end{array}$ & $\begin{array}{l}\text { STS } \\
\text { (1) }\end{array}$ & Skor \\
\hline \multicolumn{8}{|c|}{ Appropriateness Recognizability } \\
\hline 1 & $\begin{array}{l}\text { Apakah aplikasi yang dibuat } \\
\text { sangat membantu untuk melihat } \\
\text { stok barang? }\end{array}$ & 3 & 2 & 0 & 0 & 0 & 23 \\
\hline 2 & $\begin{array}{l}\text { Apakah dengan adanya aplikasi } \\
\text { ini mempermudah informasi } \\
\text { barang? }\end{array}$ & 0 & 4 & 1 & 0 & 0 & 19 \\
\hline 3 & $\begin{array}{l}\text { Apakah Aplikasi ini sesuai } \\
\text { dengan kebutuhan saya? }\end{array}$ & 0 & 1 & 3 & 0 & 0 & 13 \\
\hline 4 & $\begin{array}{l}\text { Apakah Aplikasi ini memudahkan } \\
\text { saya untuk pemesanan barang? }\end{array}$ & 0 & 4 & 0 & 0 & 1 & 12 \\
\hline 5 & $\begin{array}{l}\text { Apakah Aplikasi ini berjalan } \\
\text { sesuai dengan apa yang saya } \\
\text { harapkan? }\end{array}$ & 0 & 1 & 3 & 0 & 1 & 14 \\
\hline \multicolumn{8}{|c|}{ Operability } \\
\hline 6 & Aplikasi ini mudah dipakai? & 0 & 5 & 0 & 0 & 0 & 20 \\
\hline 7 & $\begin{array}{l}\text { Aplikasi ini mudah untuk } \\
\text { dipahami? }\end{array}$ & 0 & 2 & 3 & 0 & 0 & 17 \\
\hline 8 & $\begin{array}{l}\text { Tidak terdapat kesulitan dalam } \\
\text { menggunakan aplikasi ini? }\end{array}$ & 0 & 1 & 4 & 0 & 0 & 16 \\
\hline 9 & $\begin{array}{l}\text { Saya dapat memesan barang } \\
\text { dengan mudah menggunakan } \\
\text { aplikasi ini? }\end{array}$ & 0 & 1 & 4 & 0 & 0 & 16 \\
\hline 10 & $\begin{array}{l}\text { Apakah aplikasi ini sudah } \\
\text { berjalan sesuai dengan aturan? }\end{array}$ & 0 & 0 & 2 & 2 & 1 & 11 \\
\hline \multicolumn{8}{|c|}{ Learnability } \\
\hline 11 & $\begin{array}{l}\text { Saya belajar menggunakan } \\
\text { aplikasi ini dengan cepat dan } \\
\text { mudah }\end{array}$ & 0 & 1 & 4 & 0 & 0 & 19 \\
\hline 12 & $\begin{array}{l}\text { Saya mudah mengingat cara } \\
\text { menggunakan aplikasi ini }\end{array}$ & 0 & 5 & 0 & 0 & 0 & 20 \\
\hline 13 & Aplikasi ini mudah dipelajari & 0 & 3 & 2 & 0 & 0 & 18 \\
\hline \multicolumn{8}{|c|}{ User Interfaces Aesthetic } \\
\hline 14 & Saya puas dengan aplikasi ini & 0 & 0 & 2 & 3 & 0 & 12 \\
\hline 15 & $\begin{array}{l}\text { Saya akan merekomendasikan } \\
\text { aplikasi ini kepada teman-teman } \\
\text { saya }\end{array}$ & 0 & 0 & 5 & 0 & 0 & 15 \\
\hline 16 & $\begin{array}{l}\text { Apakah kesesuian tampilan } \\
\text { aplikasi ini baik? }\end{array}$ & 0 & 2 & 3 & 0 & 0 & 17 \\
\hline
\end{tabular}

Tabel 12. Hasil Pengujian aspek Usability Pengguna (Lanjutan) 


\begin{tabular}{|c|c|c|c|c|c|c|c|}
\hline No & Instrumen & $\begin{array}{l}\text { SS } \\
(5)\end{array}$ & $\begin{array}{l}S \\
(4)\end{array}$ & $\begin{array}{l}\text { KS } \\
\text { (3) }\end{array}$ & $\begin{array}{l}\text { TS } \\
(2)\end{array}$ & $\begin{array}{c}\text { STS } \\
(1)\end{array}$ & Skor \\
\hline \multicolumn{8}{|c|}{ User Error Protection } \\
\hline 17 & $\begin{array}{l}\text { Jika ada kolom yang tidak diisi } \\
\text { maka keluar notifikasi }\end{array}$ & 2 & 3 & 0 & 0 & 0 & 22 \\
\hline \multicolumn{8}{|c|}{ Accessibility } \\
\hline 18 & $\begin{array}{l}\text { Apakah Aplikasi ini dapat } \\
\text { digunakan oleh pelanggan? }\end{array}$ & 0 & 5 & 0 & 0 & 0 & 20 \\
\hline 19 & $\begin{array}{l}\text { Apakah Aplikasi ini dapat } \\
\text { digunakan dalam jangka yang } \\
\text { panjang? }\end{array}$ & 1 & 0 & 4 & 0 & 0 & 17 \\
\hline 20 & $\begin{array}{l}\text { Apakah Kemudahan pada aplikasi } \\
\text { ini akan membantu pelanggan } \\
\text { dalam pemesanan barang dan } \\
\text { konfirmasi pembayaran? }\end{array}$ & 0 & 4 & 1 & 0 & 0 & 17 \\
\hline \multicolumn{7}{|c|}{ Total } & 340 \\
\hline
\end{tabular}

Berdasarkan hasil pengujian pada aspek usability diatas, maka diperoleh skor pengujian sebesar 340, untuk skor maksimal pada pengujian usability didapatkan jika semua responden menjawab "Sangat Setuju" kemudian dikalikan dengan jumlah pertanyaan. Jadi skor maksimal yaitu (5 x 5) x $20=500$. jika dihitung menggunakan skala Likert dan hasil kriteria bisa dilihat pada tabel sebagai berikut :

Tabel 13. Kriteria Interpretasi Tanggapan Responden

\begin{tabular}{|c|c|l|}
\hline No & Nilai & \multicolumn{1}{|c|}{ Hasil } \\
\hline 1 & $80 \%-100 \%$ & Sangat Baik \\
\hline 2 & $60 \%-79 \%$ & Baik \\
\hline 3 & $40 \%-59 \%$ & Netral \\
\hline 4 & $20 \%-39 \%$ & Buruk \\
\hline 5 & $0 \%-19 \%$ & Sangat Buruk \\
\hline \multicolumn{3}{|c|}{ Sumber: (Sugiyono, 2015) }
\end{tabular}

$$
\begin{aligned}
\text { Hasil } & =\frac{\text { Skor diperoleh }}{\text { Skor Maksimal }} \times 100 \% \\
\text { Hasil } & =\frac{340}{500} \times 100 \% \\
\text { Hasil } & =68 \%
\end{aligned}
$$

Berdasarkan kriteria tanggapan responden pada Tabel diatas, hasil pengujian usability pada aplikasi Fisago.co yang mendapatkan skor $68 \%$ dapat disimpulkan bahwa aplikasi ini mendapatkan respon Baik dari pengguna. Kemudian usability di presentase menjadi menjadi sebuah tabel hasilnya dapat dilihat pada tabel sebagai berikut. 
Tabel 14 Presentase Usability Pengguna

\begin{tabular}{|c|l|c|c|c|}
\hline No & \multicolumn{1}{|c|}{ Nama } & $\begin{array}{c}\text { Total } \\
\text { Responden }\end{array}$ & $\begin{array}{c}\text { Hasil } \\
\text { Perhitungan }\end{array}$ & Presentase \\
\hline 1 & Appropriateness Recognizability & 81 & 64 & $64,8 \%$ \\
\hline 2 & Operability & 80 & 64 & $64 \%$ \\
\hline 3 & Learnability & 57 & 76 & $76 \%$ \\
\hline 4 & User Interfaces Aesthetic & 44 & 76 & $76 \%$ \\
\hline 5 & User Error Protection & 22 & 88 & $88 \%$ \\
\hline 6 & Accessibility & 56 & 74 & $74,6 \%$ \\
\hline
\end{tabular}

Pada tabel diatas kemudian dipresentasekan menjadi sebuah gambar sebagai berikut.

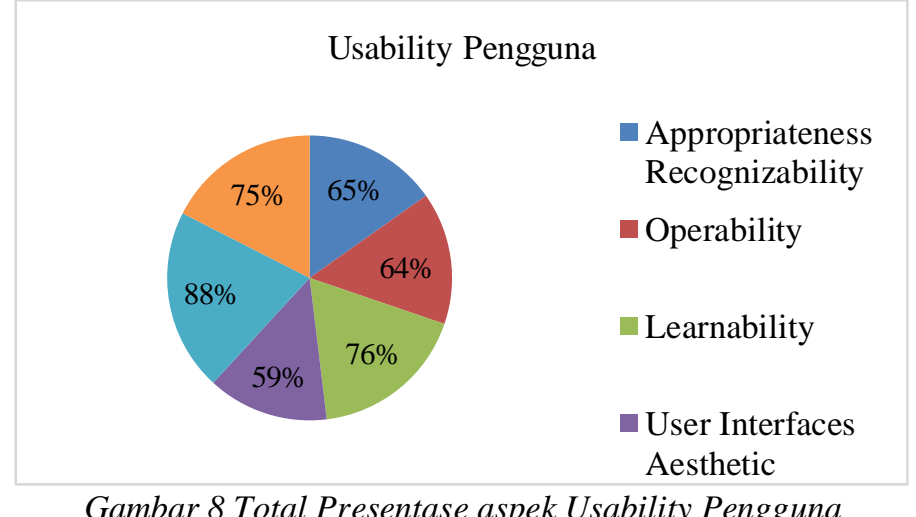

Gambar 8 Total Presentase aspek Usability Pengguna

Berdasarkan gambar diatas menjelaskan bahwa User Error Protection mendapatkan respon yang baik dari sisi pengguna.

\section{Pengujian aspek Portability}

Pengujian portability dilakukan mengacu tingkat efektivitas dan efisiensi sistem atau komponen yang dapat dipindahkan dari perangkat keras atau digunakan di lingkungan yang berbeda. Pengujian ini dilakukan dengan menggunakan empat spesifikasi smartphone yang berbeda-beda dapat dilihat pada tabel sebagai berikut.

\section{Tabel 15 Spesifikasi Smartphone}

\begin{tabular}{|c|l|l|l|}
\hline No & Merk Smartphone & RAM & $\begin{array}{c}\text { Versi } \\
\text { Android }\end{array}$ \\
\hline 1 & Vivo Y91C & $3 \mathrm{~GB}$ & 8 \\
\hline 2 & Vivo Y12 & $3 \mathrm{~GB}$ & 10 \\
\hline
\end{tabular}


Tabel 16. Spesifikasi Smartphone

\begin{tabular}{|c|l|l|l|}
\hline No & $\begin{array}{c}\text { Merk } \\
\text { Smartphone }\end{array}$ & RAM & $\begin{array}{c}\text { Versi } \\
\text { Android }\end{array}$ \\
\hline 3 & Oppo A33 & 3 GB & 10 \\
\hline 4 & Redmi note 5 & 4 GB & 8 \\
\hline
\end{tabular}

Pengujian aspek portability yang diuji adalah proses instalasi dimana apliaksi dapat terpasang pada perangkat kemudian ketika aplikasi dibuka dapat berjalan dan tampilan sesuian dengan resolusi masing-masing layar. Tabel hasil pengujian dapat dilihat pada tabel sebagai berikut.

Tabel 17. Hasil Pengujian Portability

\begin{tabular}{|c|l|l|l|c|}
\hline No & Merk Smartphone & Proses Instalasi & $\begin{array}{c}\text { Ketika } \\
\text { Dijalankan }\end{array}$ & Resolusi \\
\hline 1 & Vivo Y91C & Terinstal & Lancar & Sesuai Layar \\
\hline 2 & Vivo Y12 & Terinstal & Lancar & Sesuai Layar \\
\hline 3 & Oppo A33 & Terinstal & Lancar & Sesuai Layar \\
\hline 4 & Redmi note 5 & Terinstal & Lancar & Sesuai Layar \\
\hline
\end{tabular}

Berdasarkan pengujian aspek portability tabel 5.17, maka didapatkan hasil pengujian pada aplikasi dapat terinstal dan dapat dijalankan dengan baik dengan spesifikasi yang berbeda-beda.

\section{SIMPULAN}

Penulis membangun aplikasi E-Commerce Fisago.co berbasis android dengan melakukan pengumpulan data melalui wawancara kepada pemilik toko Fisago.co dan melalukan observasi untuk mengetahui proses penjualan yang dilakukan selama ini. selanjutnya penulis melakukan perancangan interface kemudian dalam proses pembuatan aplikasi penulis menggunakan software Android Studio. Guna mempermudah pelanggan dalam membeli, membayar, dan melihat stok barang dilakukan pengujian alpa dan beta menggunakan aspek pengujian ISO 25010 dengan memberikan pertanyaan melalui kuisoner kemudian hasil tersebut dihitung menggunakan skala pengukur yaitu Skala Likert, pengujian aplikasi E-Commerce Fisago.co berbasis android pada functionlity suitability mendapatkan skor $94 \%$ dan untuk pengujian usability mendapatkan $68 \%$ dari sisi pengguna dengan kriteria "Baik" kemudian dari sisi admin mendapatkan skor 92\% dengan kriteria "Sangat Baik". Pada Pengujian aspek portability dengan spesifikasi smartphone yang berbeda dapat terinstal dan dapat berjalan dengan baik. Aplikasi E-Commerce Fisago.co berbasis android layak digunakan sebagai aplikasi dalam pembelian barang, konfirmasi pembayaran dan melihat ketersedian stok barang.

\section{UCAPAN TERIMA KASIH}

Puji syukur penulis panjatkan kepada Tuhan YME, karena atas berkat dan rahmat-Nya, penulis dapat menyelesaikan skripsi ini. Penulisan skripsi ini dilakukan dalam rangka memenuhi salah satu syarat untuk mencapai gelar sarjana pada Program Studi Informatika Fakultas Teknik dan Imu Komputer Universitas Teknokrat Indonesia. Penulis menyadari bahwa, tanpa bantuan dan bimbingan dari berbagai pihak, dari masa perkuliahan sampai ada penyusunan skripsi ini, sangatlah sulit bagi penulis untuk menyelesaikan laporan ini. Oleh karena itu, penulis mengucapkan terimakasih kepada:

1. Dr. H.M. Nasrullah Yusuf, S.E., M.B.A., selaku Rektor Universitas Teknokrat Indonesia. 
2. Dr. H. Mahathir Muhamadm S.E., MM., selaku Dekan Fakultas Teknik dan Imu Komputer Universitas Teknokrat Indonesia.

3. Ibu Dyah Ayu Megawaty, M.Kom., selaku Ketua Jurusan Program Studi S1 Sistem Informasi Fakultas Teknik dan Imu Komputer Universitas Teknokrat Indonesia.

4. Ibu Lathifah, S.T., M.Kom., selaku dosen pembimbing yang telah membimbing saya pada skripsi ini.

5. Bapak Yuri Rahmanto, M.Kom., selaku dosen penguji yang telah memberikan masukan pada skripsi ini.

\section{REFERENSI/DAFTAR PUSTAKA}

Abdi Pandu Kusuma, K. A. (2017). PERANCANGAN DAN IMPLEMENTASI E-COMMERCE UNTUK PENJUALAN BAJU ONLINE BERBASIS ANDROID. Jurnal Antivirus, Vol. 11 No. 1 Mei 2017, 1-11.

Alfon Borneo Simanjuntak, Y. A. (2020). RANCANG BANGUN APLIKASI E - COMMERCE UNTUK PENJUALAN KAMERA DAN AKSESORIS (Studi Kasus: Monggopro, Yogyakarta).

Andi Dwi Riyanto, K. M. (2016). APLIKASI M-COMMERCE BERBASIS ANDROID PADA ZONA KOMPUTER BANJARNEGARA. Jurnal Telematika Vol 9 No. 1 Februari 2016, 67-77.

Arif Tirtana, A. Z. (2020). Rancang Bangun Aplikasi E-Commerce Guna Meningkatkan Pendapatan UMKM. Jurnal Ilmiah Teknologi Informasi Asia Vol.14, No. 2, Tahun 2020, 101-108.

duniafintech.com. (2018, maret 24). E-COMMERCE, MIDTRANS PAYMENT GATEWAY. Retrieved from duniafintech: https://duniafintech.com/midtrans-payment-gateway-e-commerce/

Erwin Yulianto, H. H. (2019). RANCANG BANGUN PERANGKAT LUNAK E-COMMERCE MENGGUNAKAN METODE MARKET BASKET ANALYSIS. Media Informatika Vol.18 No. 1 2019, 19-36.

Fatkhurohman, F. (2020). RANCANG BANGUN APLIKASI E-COMMERCE UNTUK PENJUALAN GENSET.

Fergiawan Listianto, F. R. (2017). APLIKASI E-COMMERCE BERBASIS WEB MOBILE PADA INDUSTRI KONVEKSI SERAGAM DRUMBAND DI PEKON KLATEN GADINGREJO KABUPATEN PRINGSEWU. Jurnal TAM (Technology Acceptance Model) Volume 8, Nomor 2, Desember 2017, 146-152.

Jogiyanto, H. (2010). Analisa dan Desain Sistem Informasi.

Lathifah, S. (2020). Penerapan Enterprise Architecture Pada Penerimaan Mahasiswa Baru Menggunakan TOGAF Di Universitas X Palembang. Jurnal Teknik Informatika dan Sistem Informasi, .7, 647-655.

Lathifah, S. M. (2021). PEMODELAN ENTERPRISE ARCHITECTURE MENGGUNAKAN TOGAF PADA UNIVERSITAS X PALEMBANG. Jurnal TEKNOINFO, 7.

Pahlevy. (2010). Pengertian Flowchart dan definisi data. Retrieved from https://www.seputarpengetahuan.co.id/2020/09/flowchart.html

Rosadi, M. \&. (2015). PERANCANGAN APLIKASI E-COMMERCE (STUDI KASUS: DISTRIBUTOR COKLAT BANDUNG). Jurnal Computech \& Bisnis, Vol. 9, No. 1, Juni 2015, 58-72, 58-72.

Sandi Ardiansyah, M. S. (2019). RANCANG BANGUN E-COMMERCE TOKO FURNITURE. Jurnal Informatika, Volume 8, No.1, Juni 2019, 23-31.

Sandro Alfeno, W. I. (2018). APLIKASI MOBILE COMMERCE (M-COMMERCE) BERBASIS ANDROID HYBRID. 169179.

Sugiyono. (2010). Metode penelitian pendidikan. Bandung.

Sugiyono. (2015). Metode Penelitian Kuantitatif Kualitatif R\&B. Bandung: Aflabeta.

Sunny Samsuni, E. E. (2018). RANCANG BANGUN APLIKASI E-COMMERCE PENJUALAN PRODUK KECANTIKAN DAN FASHION PADA AC FASHION STYLE. Jurnal PROSISKO Vol. 5 No. 2 September 2018 , 79-86. 
Jurnal Informatika dan Rekayasa Perangkat Lunak (JATIKA), Vol: 2, No: 3, 285-303

Warsita, B. (2011). Landasan Teori Dan Teknologi Informasi Dalam Pengembangan Teknologi Pembelajaran. Jurnal Teknodik Vol. XV, Nomor 1, Juli 2011, 84-96.

Wong, J. (2010). Internet Marketing for Beginners, Elex Media Komputindo. Jakarta. 